\title{
Brown Coal in Victoria, Australia and Maddingley Brown Coal Open Cut Mine Batter Stability
}

\author{
Lei Zhao, Greg You \\ School of Science, Engineering and Information Technology, Federation University Australia, University Drive, \\ Mt Helen, Vic 3353, Australia \\ E-mail: leizhao2@students.federation.edu.au (Corresponding author); \\ g.you@federation.edu.au (Corresponding author)
}

Received: 12 February 2020; Accepted: 28 March 2020; Available online: 20 May 2020

\begin{abstract}
Brown coal is young, shallowly deposited, and widely distributed in the world. It is a fuel commonly used to generate electricity. This paper first reviews the resources and characteristics of brown coal in Victoria, Australia, and its exploitation and contribution to the economy or power supply in Victoria. Due to the shallow depth of the brown coal seam, e.g. very favorable stripping ratio, open pit mining is the only mining method used to extract the coal at low cost for power generators. With the large-scale mining operations, cases of batter failure were not rare in the area. From the comprehensive review of past failures, overburden batter tends to fail by circular sliding, coal batter tends to fail by block sliding after the overburden is stripped due to a weak waterbearing layer underneath the coal seam and tension cracks developed at the rear of the batter, and batter failure is typically coincided with peak raining seasons. Secondly, the paper reviews the case study of Maddingley Brown Coal (MBC) Open Cut Mine batter stability, including geology, hydrogeology, and hydro-mechanically coupled numerical modelling. The modelling employs three-dimensional finite element method to simulate the MBC northern batter where cracks were observed in November 2013. The comprehensive simulation covers an overburden batter, a brown coal batter, two rainfall models, and a buttressed batter. The simulated results agree well with observed data, and it is found that the rainfall at the intensity of $21 \mathrm{~mm}$ substantially lowered the factor of safety of the coal batter.
\end{abstract}

Keywords: Batter stability; Brown coal; Block failure; Finite element analysis; Rainfall; Three-dimensional numerical modelling.

\section{Introduction}

Coal is a very important nonrenewable energy resource. It is formed from the ancient plants that experienced high pressure and temperature millions of years ago. The forming process can be divided into different stages which are plants (wood), peat, brown coal (lignite) and black coal based on the forming sequence. Each successive stage has a higher energy content and lower water content [1]. Victorian brown coal is low rank energy resource coal.

Victoria is well-known for its huge quantity of reserved brown coal (approximately 430 billion tons of in situ brown coal, 65 billion tons of measured coal, 33 billion tons of potentially economic brown coal) reported by the Department of Economic Development, Jobs, Transport and Resources, Victoria, Australia [2], which represents $22.6 \%$ of the world's recoverable economic demonstrated resource of brown coal [3]. In Australia, $97 \%$ of total brown coal resource is in Victoria, and 99\% of economic demonstrated brown coal resource is in the state.

More than $80 \%$ of brown coal deposits is located in the Gippsland Basin in Victoria; it is also found in the Otway Basin and across the Murray Basin [2]. The distribution of brown coal in Victoria is shown in Figure 1. In the Latrobe Valley, Gippsland, Victoria, Australia, there are three large brown coal open cut mines as follows.

1) Hazelwood Open Cut Mine: commenced in 1959, pit area $10 \mathrm{~km} 2$, pit depth 120m, and closed in 2017.

2) Loy Yang Open Cut Mine: commenced in 1984, pit area $60 \mathrm{~km} 2$, pit depth 200m, 28 million ton/a of coal production, planned closure in 2048.

3) Yallourn Open Cut Mine: commenced in 1972, pit depth 90m, 17 million ton/a of coal production, planned closure in 2032.

As the main fuel for generating electricity in Victoria, brown coal has played an extremely important role in Victoria's economy. Brown coal has been exploited by open cut mining in the Latrobe Valley since 1921 [4] and the Yallourn power plant and brown coal mine began to provide power to Melbourne in June 1924 [5]. As the shallow depth and large coal thickness favorites low-cost and large-scale open pit mining, Victoria brown coal is 
one of the cheapest energy sources available to the state. Six power stations provide 90 percent of Victoria's electricity demand. It is estimated that the abundant brown coal resources can power Victoria for centuries at current usage level [6]. Although its high moisture content prevents it from export, technologies developed during the past decade are recognized to improve the situation, such as the coal de-watering technology which converts raw brown coal to a high quality fuel that can be stored, transported and exported [7]. More recently, the Commonwealth and local governments funded a project called the Hydrogen Energy Supply Chain (HESC) that attempts to turn brown coals to hydrogen and then transport it the Port of Hastings where it will be liquefied and shipped to Japan [8]. In spite of the gradual decrease of brown coal consumption in energy field due to the application of renewable resources, the brown coal exploitations may still be a viable operation in the future, as long as the mining operation are effectively optimized and managed [9]. Therefore, the exploration and application of the enormous brown coal reserves in Victoria would shave a glorious prospect in the future.

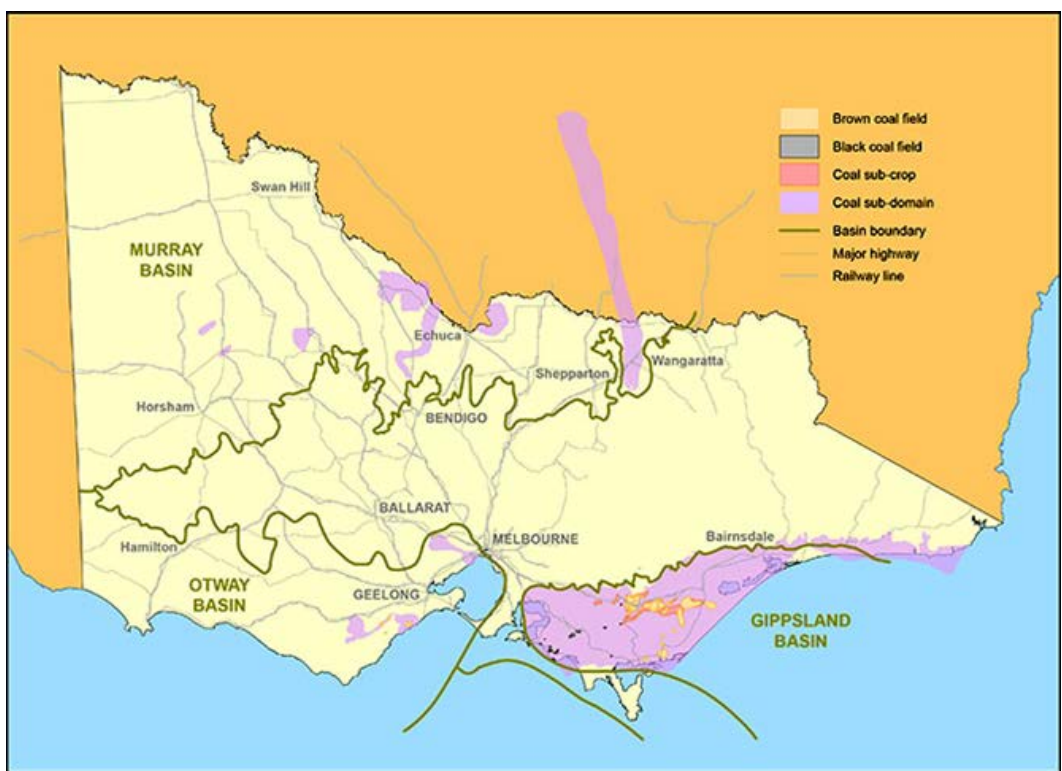

Figure 1. Brown Coal distribution of brown coal reserves in Victoria, Australia [2]

\section{Characteristics of Victorian brown coal}

Victorian brown coal is a soft to hard lignite. It is low in ash ( $<4 \%$ on a dry weight basis), Sulphur $(<1 \%)$, nitrogen $(<1 \%)$ and heavy metals, and high in moisture content (48\%-70\%) that reduces its effective energy content (average $8.6 \mathrm{MJ} / \mathrm{kg}$ on a net wet basis or $26.6 \mathrm{MJ} / \mathrm{kg}$ on a gross dry basis) [2]. It has low density (specific gravity < 1.2). Its void ratio typically ranges between 1.0 and 2.0, while it is mostly less than 1.0 for inter-seam materials [10]. Some energy and physical properties of brown coal are shown in Table 1.

Table 1. Properties of Victorian brown coal [2, 10]

\begin{tabular}{ll}
\hline Properties & Value \\
\hline Energy value (net wet) & 5.8 to $11.5 \mathrm{MJ} / \mathrm{kg}$ \\
Energy value (gross dry) & 25 to $29 \mathrm{MJ} / \mathrm{kg}$ \\
Carbon & 65 to $70 \%$ \\
Oxygen & 25 to $30 \%$ \\
Hydrogen & 4 to $5.5 \%$ \\
Unit weight (dry) $\left(\mathrm{kN} / \mathrm{m}^{-3}\right)$ & 5.2 \\
Unit weight $\left(\right.$ saturated) $\left(\mathrm{kN} / \mathrm{m}^{-3}\right)$ & 11.74 \\
Overburden thickness & 10 to 20 meters \\
Strip ratio $\left(\mathrm{m}^{3} / \mathrm{m}^{3}\right)$ & 0.2 to 2.0 \\
\hline
\end{tabular}

Victoria brown coal is high in organic content ( $>90 \%)$, but low in hydraulic conductivity [11-13]. Its strength is between normal engineering soils and rocks, and the average undrained shear strength is between 550 and 1,100 $\mathrm{kPa}[14,15]$. The average tensile strength is $101.4 \mathrm{kPa}$ from direct tensile tests and is $112 \mathrm{kPa}$ based on the Brazilian test [16].

From 1D consolidation tests, Victoria brown coal demonstrated such consolidation behaviors as large deformation, immediate settlement after loading and low permeability [17]. The creep effect observed was 
attributed to the compressibility of high content organic matter $[17,18]$. [10] reported that brown coal and interseam demonstrated different stress vs strain relations under 1D consolidation tests.

\section{Maddingley brown coal (MBC) open pit, Bacchus, Australia}

\subsection{MBC site description}

The Maddingley brown coal (MBC) open pit is located 2km south of Bacchus Marsh township and 60km northwest of Melbourne, Victoria, Australia. The site is bound by East Maddingley Road, Tilley’s Road, GeelongBacchus Marsh, Kerr's and Cummings Roads. Parwan Creek bounds the mine on the southern boundary [19]. It is a small mine and has been mined since 1943. Initially, it was underground mining and converted to open cut mining in 1946. Since the late 1940s, brown coal extracted from MBC had been used as boiler fuel for numerous industries in Victoria. Thus, the annual production rate increased to half million tons by the mid-1950s and the level was maintained until the late 1960s due to the application of natural gas. The MBC brown coal was then altered for agricultural use. By that time the total number of mined brown coal from the site reached 10 million tons. The brown coal reserve is 40 million in the Maddingley Mining Tenement at Bacchus Marsh [7]. The level of mining production is maintained in a small scale at present and brown coal is sold as compost and garden fertilizer [20]. The current coal extraction is achieved by the operation processes of overburden removal using excavating equipment (no blasting required), benches establishment and coal excavation, coal loading into trucks for transport to coal processing plant, crushing into appropriate sizes for fuel and soil additive use. Excavators, crushers, and trucks are the main mining equipment in MBC. In addition to brown coal, the extraction of aggregate, sand, and clay for rehabilitation and construction, is also included in the mining production [21]. The simultaneous coal excavation and waste landfill operation are in progress at present. Currently the brown coal extraction occurs in the north pit (Fig. 2) in a northerly direction. The mined pit has been used as a landfill since 1978. By now the stage 1 landfilling is close to complete and landfilling will continue to the neighboring stage 2 landfill cell. The typical landfill waste is rubbish materials with plastic, bricks, fabric, shredded automotive tyres, acid sulphate soils and metal recycling shredder residue [22, 23]. A 13.5 to $20 \mathrm{~m}$ wide firewall that consists of a $1 \mathrm{~m}$ compacted clay base with an integral leachate drainage system and two compacted clay outer walls approximately $4-5 \mathrm{~m}$ in width was constructed in the interface between landfill and coal, acting as a separation barrier to prevent any movement of leachate from the landfill and as a fire protection barrier between coal and the inert landfill material [7, 24].

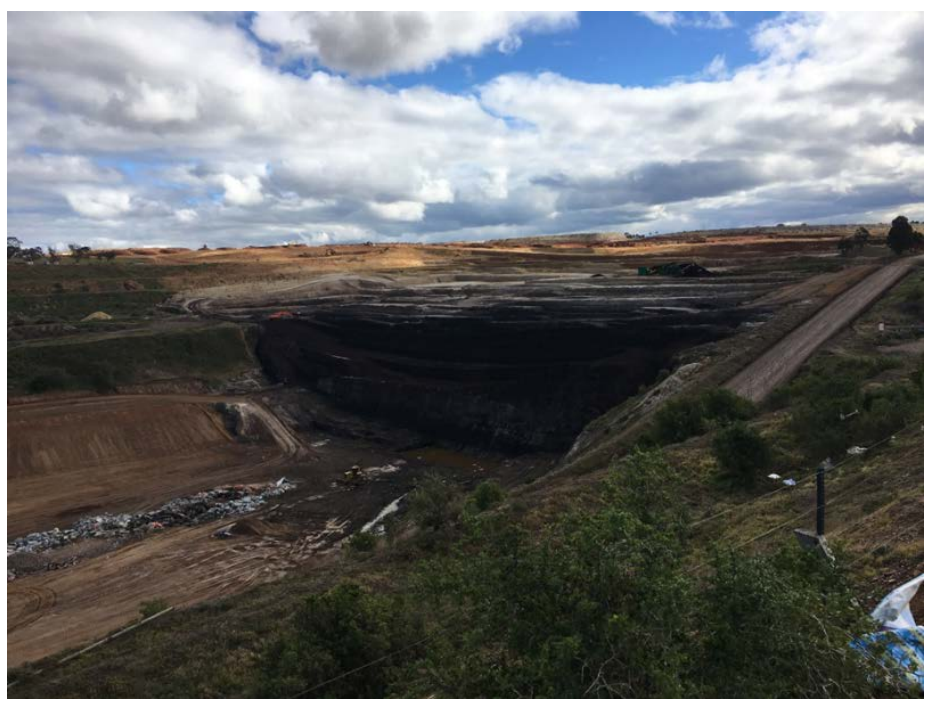

Figure 2. MBC north batter in August 2017

\subsection{Geology and hydrogeology}

The brown coal resource in the Parish of Parwan lies within the north-westerly trending embayment of the Port Phillip Basin formed in the Tertiary period. The Rowsley fault is the west boundary of the embayment and the Mesozoic rocks define the south-east. The north and south edge of the basin are marked by outcrops of Palaeozoic sediments and granites respectively [7]. The geological map of the region is shown in Figure 3.

The Maddingley coal seam at Bacchus Marsh is a stratum of the Werribee Formation and is generally underlain by the gravel layer of Lerderderg Formation or undifferentiated sediments of the Lower Werribee Formation (LWF). The coal may be conformably overlain by fluviatile clays, sands and minor gravels of the Werribee Formation, marine silts, sands and clay of the Fyansford Formation and by Quaternary basalts to the south and south-west. The Fyansford Formation is generally overlain by Quaternary Newer Volcanics and/or Quaternary 
aged sediments which were deposited as river terrace or alluvial river deposits. Quaternary basalt in the area belongs to the Newer Volcanic Group and was deposited across much of the Werribee Plains area as a sheet like lava flow. Sandy, silty and clayey gravels (predominantly sub-rounded quartz and quartzite gravel) of the Bullengarook gravels may also be found in the region overlying the Fyansford Formation and were deposited contemporaneously with the Newer Volcanic Group and can be found to interfinger with these basalt flows. Basement rocks in the region are considered to be Ordovician sediments and Devonian granodiorite rock [21]. The main geological units related to the site are shown in Figure 4.

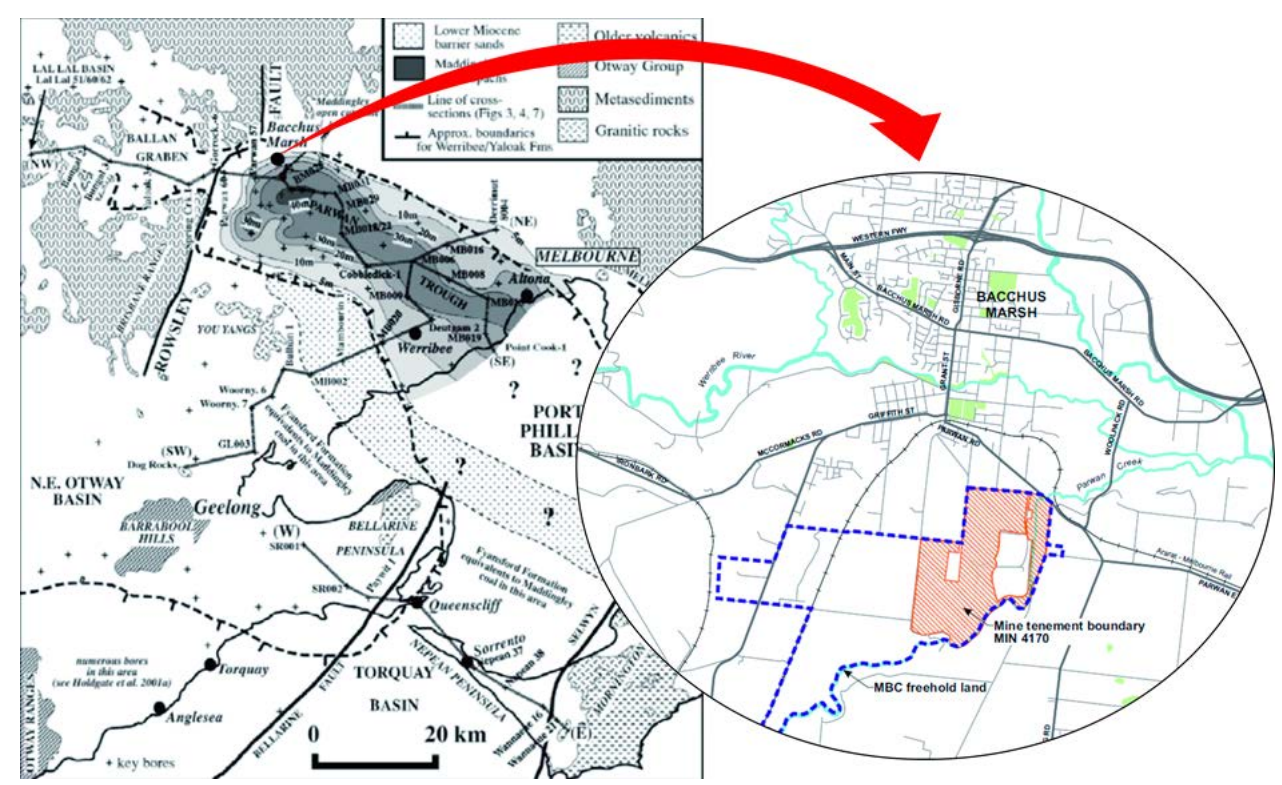

Figure 3. Structural features of the region and isopachs of the Maddingley Coal Seam [25]

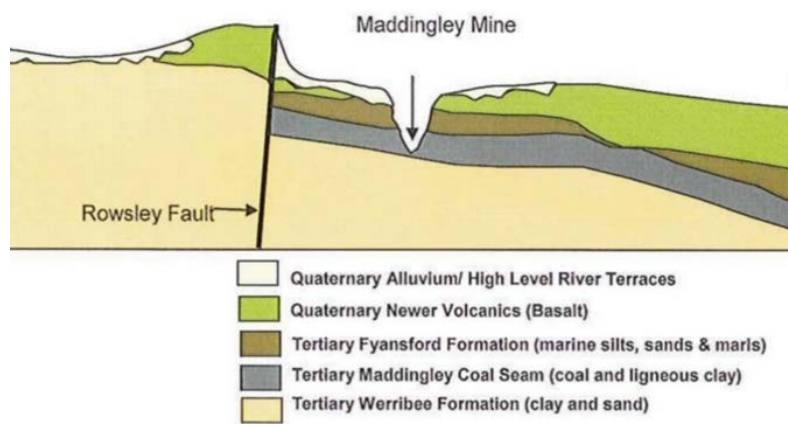

Figure 4. NW-SE Geological cross-section of MBC mine site, Bacchus Marsh, Australia [26]

The Maddingley coal seam occurs in the Port Phillip sunkland which is bounded to the west by the Rowsley Fault scarp and to the north by the highlands of the Great Dividing Range. It is a part of the Werribee plains that extend to the coast and is covered by the Newer Volcanics (basalt) which rest on the sand and clay overlying the Tertiary rocks containing the brown coal. The Maddingley coal seam has a length of 35km, width of $10 \mathrm{~km}$ to $15 \mathrm{~km}$ and thickness between $35 \mathrm{~m}$ and $60 \mathrm{~m}$. The coal seam thins and splits rapidly to the west of the Bacchus Marsh Open Pit, and grades laterally into ligneous clay and sand. Also, it thins dramatically near the north edge of the Tertiary basin. The seam generally thickens in a south and south-easterly direction but is overlain by an increasingly thick layer of Quaternary basalt. The coal is rarely fractured and is predominantly a dark brown earthy variety of lignite, with areas of abundant plant remains and woody material. The coal seam may be locally pyrtic and clayey, and generally there is little impurity although towards the base of the seam, a small percentage of the matrix may be silty or sandy [7].

Extents of the Parwan Trough are defined by the main tectonic activities (the movement along the faults) in the area. The main fault, Rowsley Fault, lies about $4 \mathrm{~km}$ west of the site and defines the western extent of the Parwan Trough. The fault runs in a north-south direction and forms a scarp about $90 \mathrm{~m}$ to $270 \mathrm{~m}$ high. Ground to the west of the fault is higher than the ground to the east. No modern movement of Rowsley Fault has been recognized [27]. There are other faults observed within $5 \mathrm{~km}$ of the site. Djerriwarrah Fault is a north-east to south-west trending fault located east-northeast of the site; Greendale Fault and Coimadai Fault are northwest to east-southeast trending 
faults located north of the site. Those three faults are associated with the basement tectonics rather than with the development of the Trough and the nature of them are not clear [24].

MBC mime site lies within the Werribee Catchment. Werribee River and Lerderderg River are located about 1.7 and $2.4 \mathrm{~km}$ north east of the mine site. Parwan Creek borders the eastern and southern boundaries of MBC site and it is a tributary to the Werribee River. The creek originally flowed through the mine center, and it was realigned to the eastern boundary of the site in the 1940s to facilitate the mining operation. A levee was constructed to separate the site and the creek. In 1994, Parwan Creek water entered pit through some cracks developed in the southern wall of MBC. The base of the Parwan Creek lies at an elevation of around 94 to 98m AHD. The local groundwater table normally lies below the creek, as a result, the Parwan Creek will recharge the underlying aquifer and be fed by the aquifer depending on the water level aquifer under seasonal conditions. Thus, the creek is called Groundwater Dependent Ecosystem that has a strong groundwater interaction with aquifers [26].

There are three main hydrostratigraphic units underlying the mine site. The upper-most aquifer, Fyansford Formation, consisting mainly of clay, silty clay with infrequent and relatively thin bends of clayey sand. This formation acts as an unconfined aquifer. The top of the unconfined aquifer is the ground surface, and the base is defined by the Madingley coal seam. The thickness of Fyansford Formation is between 5 and $20 \mathrm{~m}$. The aquifer is likely to be highly heterogeneous, both in yield and hydraulic properties. Hydraulic conductivity is likely to be up to $10-7 \mathrm{~m} / \mathrm{s}$. The unconfined aquifer is mainly recharged by rainfall. It also discharges into the Parwan Creek. The mine dewatering system controls the groundwater flow within this aquifer. This unconfined aquifer will be removed with the stripping activity. The Maddingley Coal Seam (upper Werribee Formation) is regarded as an aquitard separating the upper unconfined Fyansford Formation from the lower confined Werribee Formation, due to its high clay content and low hydraulic conductivity $(10-8 \mathrm{~m} / \mathrm{s})$. The lower Werribee Formation is extensive across the site and its bases has not been intercepted, so the thickness of this formation at the site is not known. It consists of silty sands, sands and sandy clays with minor gravels and it is known as a confined or semi-confined aquifer [24].

The regional groundwater flow is towards the north and northeast and the Werribee and Lerderderg Rivers. But in the mining area, it is affected by mine dewatering activities at site. The local groundwater flow in Fyansford Formation is towards Parwan Creek and the mined pit [21]. From the closest meteorology station at Merrimu, the mean monthly rainfall ranged from $40.0 \mathrm{~mm}$ in January to $62.0 \mathrm{~mm}$ in November from 1974 to 2012. The mean annual rainfall was 504mm. The monthly rainfall data from 2010 to 2012 is shown in Figure 5 [26].

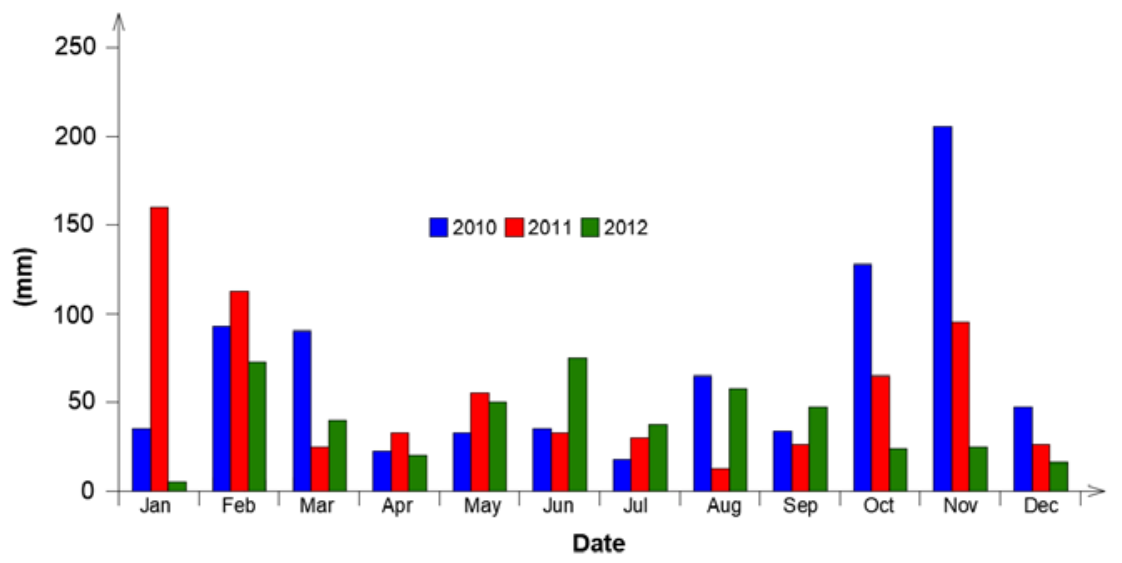

Figure 5. Monthly rainfall values (mm) for 2010, 2011 and 2012- Bacchus Marsh, Victoria

\section{Batter stability in Victorian brown coal open pits}

\subsection{Batter instability in Victorian brown coal mining}

$40 \%$ coal is mined by surface mining in the world, but $80 \%$ coal and $100 \%$ Victoria brown coal are mined by surface mining [28]. Compared with underground mining, surface mining has higher productivity and recovery of minerals. Furthermore, surface mining is free of roof collapse, gas explosion and ventilation problems. However, slope stability is a major geotechnical issue in surface mining. Open pit slope failure can cause considerable environmental damage, loss of lives, and interruption of mining production. A number of open pit walls have been formed due to brown coal mining over a century in Victoria, Australia. Current mining excavations are at large scale; Loy Yang Brown Coal Open Cut Mine has reached a depth of 200 meters [29]. As a result, the slope stability has become a major concern of potential geo-hazard in Victoria Brown Coal Open Pits. Batter failures and instability issues have been reported in this region. Two brown coal batter slips occurred at Yallourn North Open Cut Mine in 1950 and 1957. The first one occurred after a period of heavy rainfall, resulting in a 230,000 $\mathrm{m}^{3}$ of 
coal and overburden slipped into the open pit; the later one caused a slip of 500,000 $\mathrm{m}^{3}$ material [30]. The overburden of Morwell Open Cut Mine batter had a rotational circular slip while the brown coal formed block and wedge failures attributed to open joints in coal [30]. A block failure (300m across, 100m long and 50m high) occurred at the southern batter of MBC in October 1994. The failure occurred on the clay seam below the base of brown coal due to high hydrostatic pressures and resulted in water entered the mine through tension cracks [24]. Cracks were observed after a significant rainfall in Morwell Mine in February 2011 and a crack stretching 200m manifested at southern mine wall of Hazelwood open pit in February 2014 [31]. An embankment constructed to divert the Morwell River across the Yallourn mine failed during an extreme rainfall in 2012 [32]. A large block failure occurred at the northeast batter at the Yallourn East Field Mine on 14th November 2007, which was approximately $80 \mathrm{~m}$ high and 500m long, and about six million cubic meters of materials were encompassed. This block batter failure is regarded as a common batter failure type in Victorian Brown Coal open pits, and two main reasons caused this disaster which were the horizontal pressure on the brown coal block resulted from the water in the joints and the water pressure in the interseam clays underlying the block of coal [33]. This failure caused Yallourn river diverted into the mine site that resulted in over \$200 million cost to the mine and an immediate loss of one-fifth of Victorian power generation capacity [34]. Thus, it can be seen that the coal batter instability has been a problem in Victorian Brown Coal open pits. Stability assessment and control play a prominent role in the brown coal mines in Victoria, meanwhile, with the increased challenge from the expansion of brown coal mines in Victoria, to better understand the batter failure mechanism becomes more critical.

\subsection{Failure mechanism of Victorian brown coal batter}

Both geological structures and hydrogeology affect the batter stability in Victorian Brown Coal mines. From [30], the dip and strength of weak seams beneath coal, the orientation of joints, high level underground water and water pressure in joints were believed as the key factors to cause slope failure in Victorian brown coal open pits. The brown coal batter is a sandwiched geologic structure featured as a coal seam interbedded with silts, sands, and clays. In Victorian brown coal mines, batter movements and failures observed are characterized as circular sliding of overburden faces and block failure of brown coal faces [30, 35]. Corresponding to the low stripping ratio, most existing batters are brown coal faces, as a result, block sliding is likely the dominant failure type in Victoria brown coal mines. Block sliding is featured as a large block of brown coal slide horizontally towards the pit. Large movement of coal batter can occur due to low deformation modulus of brown coal after the open pit excavation, and it can lead to cracking in the coal seam. The opening up of coal joints increases the shear movements and rotations. The block sliding mechanism is shown in Figure 6.

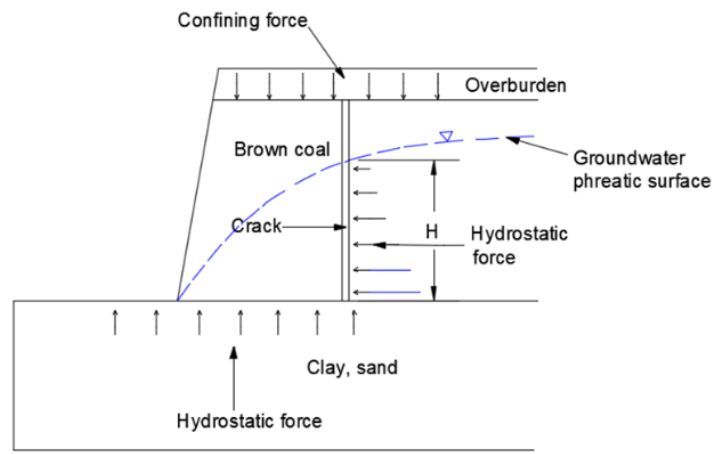

(a)

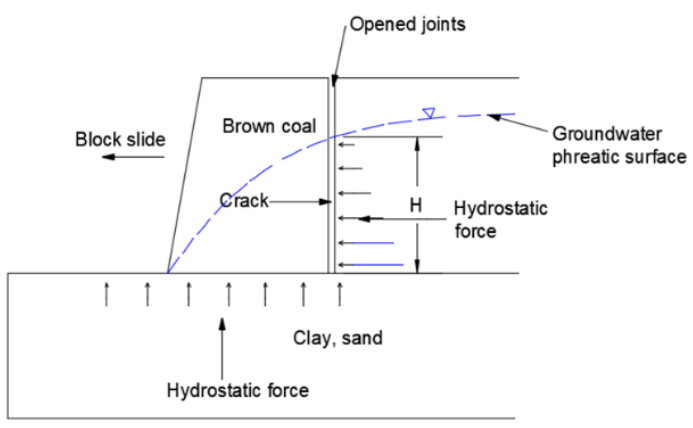

(b)

Figure 6. Victorian Brown Coal mine block sliding mechanism (a) with overburden (b) after overburden removal

Block failure often occurred not long after cracks (opened joints) emerging on coal batter surface or heavy rainfall event in Victorian brown coal open pits, as occurred in Yallourn mine in 1950 [30] and in 2007 [33]. The existence of joints is common in Victorian brown coal, which are generally steep and closed. The joints can strongly affect the batter stability as cracks tend to propagate along pre-existing joints. It has been regarded as one of the key factors causing block failure. Understanding the cracking mechanism and the effects of existing joints on the batter stability in Victoria brown coal open pits is significant to comprehensively study the block failure mechanism. Some cracks were observed on Victorian Brown Coal open pit batter. It is generally recognized that water enters joints, and the sudden increased hydrostatic water pressure pushes block to move towards the pit. After the coal block moved, the water pressure dropped. The repeated cycles of the rise-drop water pressure can lead to remarkable block movements over time, which was regarded as "stick-slip" movement [30, 35]. Preexisting joints in coal seam in Victoria are mostly steeply dipping (over $80^{\circ}$ ), only $3 \%$ of the total joints dipping between $20^{\circ}$ and $80^{\circ}$ [30]. The joints are normally smooth-walled, planar and regular, and fully penetrate the 
thickness of coal seam. Joints form block or wedge; and a critical path of block failure is normally along joints. Location, frequency, orientation and dip of joints are the most significant parameters affecting the coal batter stability [4, 30]. Being described as a serviceability failure mechanism, the brown coal block sliding requires constant field monitoring, maintenance, and preventing measures to control the frequency of occurrence and keep the magnitude of movements low [35]. The movements beyond the limit of coal cracking are attributed to consolidation movements due to elastic stress relief, which could be generated by mine site dewatering activity [4].

Water plays a critical role in the initiation of brown coal batter instability due to the relatively low unit weight of Victorian brown coal. It was recognized that much of the movements adjacent to each excavation was due to the sliding of blocks of coal under the action of the hydrostatic pressure of water in steeply dipping coal cracks in Victorian Brown Coal open pits [4]. Also, the high hydrostatic pressures in the aquifers below the pit bottom could cause floor heave once it is over the weight of the overlying layers. The high-water level can affect the final batter stability. As a consequence, preventing water entering the batter or aiding its quick release is one of the critical stability management measures. Water pumping, horizontal drainage, regular monitor of water level are the normal measures to conduct the pit water control. Although, the dewatering of aquifers could result in regional subsidence, these movements have no significant effect on pit stability. Approximately 1000 Megaliters of water was pumped out of Yallourn Mine from aquifers 40-80m beneath the pit floor to control aquifer pressure prior to 2001 [36].

On the other hand, it is interesting to note that batter failures are prone to occur in summer or close to summertime in Victoria. There is high precipitation in summer in Victoria, Australia. Figure 5 shows the distribution of precipitation in Bacchus Marsh from 2010 to 2012, where MBC mine site is located. Many reported Victorian Brown Coal batter slides or instability issues occurred not long after a rainfall event. A slip occurred in Yallourn north open pit in 1950 after a heavy rain [30]; one week after a rainfall a very large batter failure occurred at the northeast batter of the Yallourn East Field Mine on 14th November 2007 [33]; cracks were observed after a significant rainfall in Morwell Mine in February 2011 [31]; a brown coal embankment failed during an extreme rainfall at Gippsland in 2012 [32]; cracks manifested at the north batter in Maddingley Brown Coal open pit in November 2013, and further noticeable batter movements were observed after an intensive rainfall in February 2014 [37]. The rainfall related pit instability events almost concentrated in November and February when Victoria experienced the largest precipitations every year $[33,38]$. There is a significant amount of rainfall throughout the year in Victoria, an average annual rainfall amount is between $1800-2500 \mathrm{~mm}$, with heavy downpours in summer months. The recorded highest rainfall in a single day was $375 \mathrm{~mm}$ in the Otway Ranges in 1983 [39]. Therefore, rainfall is a notable factor which could cause batter instability in Victorian brown coal open pits, and a better understanding of the mechanism is helpful in predicting and managing the causal slope instabilities. However, there is no studies on the detailed analysis of the correlations between the stability of the Victorian Brown Coal open pits and rainfall event.

A clear understanding of coal batter failure mechanism is crucial for batter instability control. Though groundwater pressure, surface run-off, rainfall, coal joints, the shear strength of batter composition, batter slope and height are generally known as the factors involved in the Victorian Brown Coal open pits instability, it is a challenge to adequately interpret batter failure due to the complex interaction of those factors. Hence, more accurate slope stability assessment and failure mechanism understanding is critically required in slope failure prediction and control.

\subsection{Case study of MBC batter stability}

A crack was observed on the northern batter approximately $20 \mathrm{~m}$ from the crest of the coal face in November 2013, which opened from trace in the west to $150 \mathrm{~mm}$ wide in the east and extended 50m subparallel to the coal face. A monitoring system was established on 19 November 2013 to monitor the movements of the batter at regular interval.

Since 2016, the northern batter stability has been studied through three-dimensional finite element analysis using Plaxis3D. In the first phase of the project study, a three-dimensional geological model of north batter was constructed using the survey map in June 2012, which was 200m long, 100m wide and 109m high (Fig. 7). The groundwater was set at RL 91m in the north and at RL 60m at the pit bottom, flowing from the north to the pit bottom [40]. The finite element study is a fully coupled flow-deformation analyses to calculate the simultaneous development of deformation and pore pressures in saturated and partially saturated soils as a result of changes of the mechanical and hydraulic conditions. The numerical simulation processes include five stages, which are initial gravity loading, overburden removal, $21 \mathrm{~mm}$ rainfall, $7.6 \mathrm{~mm}$ rainfall and buttress model. Each stage includes two phases, e.g. defining the geomechanics and hydraulic state of the stage and calculating the factor of safety.

From the study, it was found that the overburden batter (Stage 1 model) tended to develop a circular critical path, e.g. potential circular failure when safety factor declines (refer to Fig. 8) and that the brown coal batter (Stage 2 model) tended to develop an "L-shaped" path, e.g. potential block failure when safety factor declines (refer to Fig. 9). The simulated safety factor was 1.4 for the batter with overburden and 1.2 for the batter after stripping 
overburden. From the simulation, a maximum value $(\Delta \varepsilon y y=0.34)$ of incremental Cartesian normal strain was generated on the part where cracks appeared after overburden removal, while the value was less than 0.06 in other parts of the model. This advised that the cracks were the results of tensile failure and were mainly attributed to the overburden removal. To be specific, a confining force from the weight of overburden, bonding coal layer and overburden, weakened with overburden stripping, which decreased the batter stability. The location of the maximum strain was bout $20 \mathrm{~m}$ from the batter crest in the model that was well agreed with the actual location of cracks. From the study, the groundwater flow assisted in worsening the movement of the batter. The coal seam heaved $0.22 \mathrm{~m}$ after overburden removal. This was in a line with the experience in Victoria open pit brown coal mines (A removal of $10 \mathrm{~m}$ thick overburden could generate a heave of about $0.15 \mathrm{~m}$.) [37]. Considering the 21 $\mathrm{mm}$ /day rainfall event on 13 November 2013 the safety factor of the coal batter dropped from 1.2 to 1.1. This was mainly due to the extra driving force towards the pit caused by the water entering the cracks.The emergency buttress effectively strengthened the stability of north batter, and the safety factor was increased to 1.43 [38].

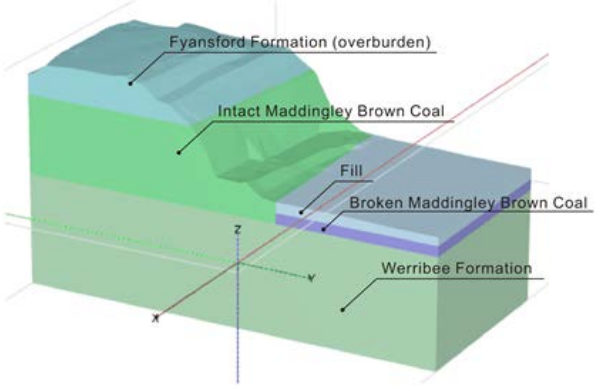

Figure 7. 3D geological model

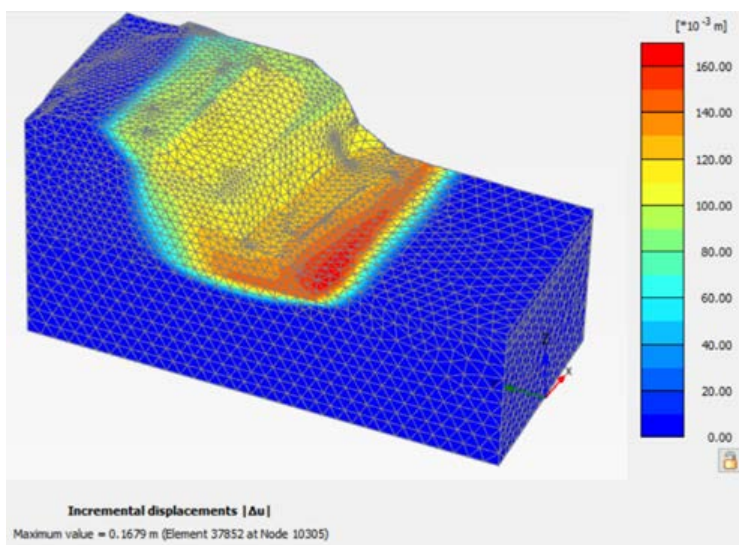

Figure 8. Simulated displacement of the overburden batter (Stage 1)

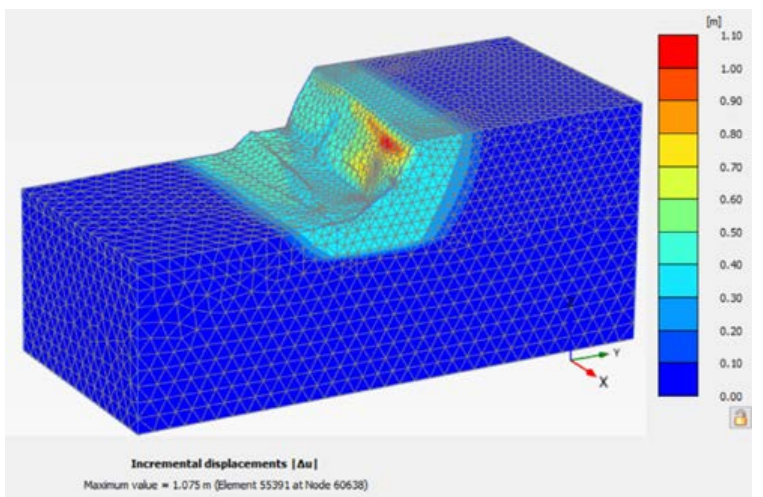

Figure 9. Simulated displacement of the brown coal batter (Stage 2 Overburden removal)

\section{Conclusions}

There are massive brown coal resources shallowly deposited in Victoria, Australia, accounting for represents $22.6 \%$ of the world's recoverable economic demonstrated resource of brown coal. It can fuel the power generators 
for centuries at the current production rate. It is low in ash, Sulphur, nitrogen and heavy metals, and high in moisture content $(48 \%-70 \%)$. It is a low energy coal. It has low density (specific gravity < 1.2). It is high in organic content $(>90 \%)$, but low in hydraulic conductivity. Its strength is between normal engineering soils and rocks, and the average undrained shear strength is between 550 and 1,100 $\mathrm{kPa}$. The average tensile strength is about $100 \mathrm{kPa}-112 \mathrm{kPa}$. Brown coal have contributed to 90\% electricity in Victoria, Australia, but long term and large-scale mining operations have led to some batter failures in the area. From the comprehensive review of past failures, overburden batter tends to fail by circular sliding, coal batter tends to fail by block sliding after the overburden is stripped due to a weak water-bearing layer underneath the coal seam and tension cracks developed at the rear of the batter, and batter failure is typically coincided with peak raining seasons. Furthermore, this paper reviews the case study of MBC Open Cut Mine batter stability through hydro-mechanically coupled numerical modelling. The modelling employs three-dimensional finite element method to simulate the northern batter where cracks up to $150 \mathrm{~mm}$ aperture were observed in November 2013. The comprehensive simulation covers an overburden batter, a brown coal batter, two rainfall models, and a buttressed batter. The simulated results agree well with observed data. The factor of safety of the overburden batter is 1.5 , and the safety factor is lowered to 1.2 for the coal batter after the overburden removal. In case of the rainfall at the intensity of $21 \mathrm{~mm}$, the factor of safety of the coal batter declined to 1.1 .

\section{Acknowledgements}

The authors sincerely express their appreciation to the support of this research project from Maddingley Brown Coal Pty Ltd., in particular, to Mr. Tim Tillig, the Environmental, Quality and Safety Officer. This study is supported by the Australian Research Training Program (RTP) Scholarship and Federation University Australia George Collins Memorial Scholarship.

\section{References}

[1] Environment Victoria. The problem with brown coal. https://environmentvictoria.org.au/our-campaigns/safeclimate/problem-brown-coal/.

[2] Department of Economic Development, Jobs, Transport and Resources, Victoria, Australia. Lignit/Brown coal. 2016. http://www.energyandresources.vic.gov.au/earth-resources/victorias-earth-resources/coal.

[3] Australian Atlas of Mineral Resources, Mines, and Processing Centers. Brown coal. 2011. http://www. australianminesatlas.gov.au/aimr/commodity/brown_coal.html.

[4] Hutchings R, Fajdiga M, Raisbeck D. The effects of large ground movements resulting from brown coal open cut excavations in the Latrobe Valley, Victoria. Development and Planning Division, Fuel Department, Safety Electricity Commission of Victoria. 1977.

[5] Wilyl J. Minerals-fact sheets-brown coal-lignite. Minerals Council of Australia-Victorian Division. 2019. https://www.scribd.com/document/357113704/Minerals-Fact-Sheets-Brown-Coal-Lignite.

[6] Minerals Council of Australia. Brown coal- lignite. 2016. http://www.minerals.org.au/file_upload/files/resou rces/victoria/minerals_fact_sheets/Minerals-Fact_Sheets-Brown Coal-Lignite.pdf.

[7] Golder Associates Pty Ltd. Mine work and operations plan revision 2. Report prepared for Maddingley Brown Coal Pty Ltd, Bacchus Marsh, Victoria, Australia. 2006.

[8] Nadel C. Converting brown coal to hydrogen? The dirty details on another coal boondoggle. Environment Victoria. 2019.https://environmentvictoria.org.au/2018/07/13/converting-brown-coal-to-hydrogen-the-dirtydetails-on-another-coal-boondoggle/.

[9] Zevgolis IE, Deliveris AV, Koukouzas NC. Slope failure incidents and other stability concerns in surface lignite mines in Greece. Journal of Sustainable Mining. 2019; 18(4): 182-197.

[10] Moein F, Xue J, Mackay R. Review of the historical data characterizing Latrobe Valley brown coal consolidation behavior. Engineering Geology Special Publications. 2016; 27: 217-226.

[11] Durie RA. The science of Victorian brown coal: Structure, properties and consequences for utilization. Butterworth Heinemann; 1991.

[12] Liu K, Mackay R, Xue J, Tolooiyan A. Experimental study of brown coal hydraulic behavior at low confining stress. In: International Conference on Unsaturated Soils 2014. Sydney, Australia. CRC Press;2014. p.11251130.

[13] Xue J, Tolooiyan A. Reliability analysis of block sliding in large brown coal open cuts. In: The 2012 World Congress on Advances in Civil, Environmental, and Materials Research (ACEM' 12). Seoul, Korea. TechnoPress;2012. p.1578-1587.

[14] Rosengren KJ. The structure and strength of Victoria brown coal. [MSc thesis]. University of Melbourne, Melbourne. 1961.

[15] Trollope DH, Rosengren KJ, Brown ET. The mechanics of brown coal. Géotechnique. 1965; 15:363-386. 
[16] Tolooiyan A, Mackay R, Xue J. Measurement of the tensile strength of organic soft rock. Geotechnical Testing Journal. 2014; 37(6):991-1001.

[17] Liu K, Xue J, Yang M. Deformation behavior of geotechnical materials with gas bubbles and time dependent compressible organic matter. Engineering Geology. 2016; 213:98-106.

[18] Yang M, Liu K. Deformation behaviors of peat with influence of organic matter. SpringerPlus. 2016; 5:573.

[19] URS Australia Pty Ltd. Community engagement plan- mining and extractive operations. Report prepared for Maddingley Brown Coal Pty Ltd, Bacchus Marsh, Victoria, Australia. 2013.

[20] URS Australia Pty Ltd. Mining and extractive operations. Report prepared for Maddingley Brown Coal Pty Ltd, Bacchus Marsh, Victoria, Australia. 2014.

[21] URS Australia Pty Ltd. Environment management plan- mining and extractive operations. Report prepared for Maddingley Brown Coal Pty Ltd, Bacchus Marsh, Victoria, Australia. 2013.

[22] Coffey Geosciences Pty Ltd. Assessment of structural integrity of firewall, south and east walls of Maddingley Brown Coal Mine, Bacchus Marsh. Report prepared for Maddingley Brown Coal Pty Ltd, Bacchus Marsh, Victoria, Australia. 2006.

[23] NSP Geotechnics Pty Ltd. Geotechnical investigation for MBC landfill project - Area awest. Report prepared for Maddingley Brown Coal Pty Ltd, Bacchus Marsh, Victoria, Australia. 2013.

[24] Golder Associates Pty Ltd. Mine risk issues assessment. Report prepared for Maddingley Brown Coal Pty Ltd, Bacchus Marsh, Victoria, Australia. 2011.

[25] Holdgate GP, Gallagher SJ, Wallace MW. Tertiary coal geology and stratigraphy of the Port Phillip Basin, Victoria. Australian Journal of Earth Sciences. 2020; 49:437-453.

[26] URS Australia Pty Ltd. Hydrogeological risk assessment Maddingley brown coal landfill. Report prepared for Maddingley Brown Coal Pty Ltd, Bacchus Marsh, Victoria, Australia. 2014.

[27] Birch WD (Editor). Geological Society of Australia special publication 23. Geological Society of Australia (Victoria Division). 2003.

[28] Australia’s Mineral Resource Assessment. Coal. 2013. https://www.ga.gov.au/data-pubs/data-andpublications-search/publications/australian-minerals-resource-assessment/coal.

[29] Langmore D. Latrobe Valley open cuts: Wastelands or treasured assets?. Planning News. 2016; 42(11): 2627. https://search.informit.com.au/documentSummary;dn=509945601620014;res=IELENG

[30] Learmonth AP. Geomechanics working in the power industry. In: The National Engineering Conference, Melbourne. 1985. p.10-18.

[31] Neison L. Monstrous crack appears in mine. Latrobe Valley Express-News. 2014. http://www. latrobevalleyexpress.com.au/story/2108192/monstrous-crack-appears-in-mine/.

[32] Hepburn S. Accidents or bad regulation? Why Victoria’s coal mines keep failing. The Australian. 2014. http://www.theaustralian.com.au/business/business-spectator/accidents-or-bad-regulation-why-victorias-coa l-mines-keep-failing/news-story/eaaba87b0ea5119a28c97393fd1dbd73.

[33] Mining Warden. Yallourn mine batter failure inquiry. 2008. https://www.parliament.vic.gov.au/ papers/govpub/VPARL2006-10No156.pdf.

[34] Sullivan T. Lessons from the Yallourn batter failure inquiry. Australian Geomechanics Society. 2011. https://australiangeomechanics.org/meetings/lessons-from-the-yallourn-batter-failure-inquiry/.

[35] Washusen JA, Fraser CJ. Stability control and monitoring in deep Latrobe Valley Open Cuts. In: The Aus. I.M.M Conference, Melbourne, Vic. 1982. p.87-95.

[36] Coulthard M, Dugan K, Rivalland J, Wood WJ. Deep aquifer shutdown tests at Yallourn Mine. Aus. IMM. https://ausimm.com/product/deep-aquifer-shutdown-tests-at-yallourn-mine/.

[37] Golder Associates Pty Ltd. Geotechnical assessment northern coal batter. Prepared for Maddingley Brown Coal. 2014

[38] Zhao L, You G. Stability study on the northern batter of MBC Open Pit using Plaxis 3D. Arabian Journal of Geosciences. 2018; 11:119.

[39] Rainfall by region: Victoria. https://www.bushmantanks.com.au/blog/rainfall-by-region-victoria/.

[40] Zhao L, You G. Cracking mechanism along the north batter of Maddingley Brown Coal Open Pit Mine, Victoria, Australia. In: Proceedings of GeoMEast2017: Engineering Geology and Geological Engineering for Sustainable Use of the Earth's Resources, Urbanization and Infrastructure Protection from Geohazards. Springer, Cham. 2017. p. 115-129.

(C) 2020 by the author(s). This work is licensed under a Creative Commons Attribution 4.0 International License (http://creativecommons.org/licenses/by/4.0/). Authors retain copyright of their work, with first publication rights granted to Tech Reviews Ltd. 